University of Nebraska - Lincoln

DigitalCommons@University of Nebraska - Lincoln

Faculty Publications: Department of

Entomology

Entomology, Department of

2011

\title{
Evaluation of Buffalograss Leaf Pubescence and Its Effect on Resistance to Mealybugs (Hemiptera: Pseudococcidae)
}

Jennifer M. Johnson-Cicalese

University of Nebraska-Lincoln, jenjc@aesop.rutgers.edu

Frederick P. Baxendale

University of Nebraska-Lincoln, fbaxendale1@unl.edu

Terrance P. Riordan

University of Nebraska-Lincoln, triordan1@unl.edu

Tiffany Heng-Moss

University of Nebraska-Lincoln, thengmoss2@unl.edu

Lisa Baird

University of San Diego, Baird@sandiego.edu

Follow this and additional works at: https://digitalcommons.unl.edu/entomologyfacpub

Part of the Entomology Commons

Johnson-Cicalese, Jennifer M.; Baxendale, Frederick P.; Riordan, Terrance P.; Heng-Moss, Tiffany; and Baird, Lisa, "Evaluation of Buffalograss Leaf Pubescence and Its Effect on Resistance to Mealybugs (Hemiptera: Pseudococcidae)" (2011). Faculty Publications: Department of Entomology. 271.

https://digitalcommons.unl.edu/entomologyfacpub/271

This Article is brought to you for free and open access by the Entomology, Department of at DigitalCommons@University of Nebraska - Lincoln. It has been accepted for inclusion in Faculty Publications: Department of Entomology by an authorized administrator of DigitalCommons@University of Nebraska - Lincoln. 


\title{
SHORT COMMUNICATION
}

\section{Evaluation of Buffalograss Leaf Pubescence and Its Effect on Resistance to Mealybugs (Hemiptera: Pseudococcidae)}

\author{
Jennifer Johnson-Cicalese, ${ }^{1}$ Frederick Baxendale, ${ }^{1}$ Terrance Riordan, ${ }^{2}$ \\ Tiffany Heng-Moss, ${ }^{1}$ And Lisa Baird ${ }^{3}$
}

Introduction

Considerable progress has been made in improving the turfgrass characteristics of buffalograss, Buchlö dactyloides (Nutt) Engelm, a native North American grass species with low maintenance requirements (Riordan et al., 1993). Two mealybugs, Tridiscus sporoboli (Cockerell) and Trionymus sp. (Hemiptera: Pseudococcidae) have emerged as buffalograss pests Baxendale et al., 1994).

Mealybugs have been associated with buffalograss stands throughout Nebraska (Baxendale et al., 1994), as well as in Texas and Arizona. Unfortunately, the Pseudococcidae are poorly described and species identification requires extensive specimen preparation (Ferris, 1950, 1953). Buffalograss mealybugs have an oblong, pale purple-grey, membranous body, ranging in length from 0.2 to $3.0 \mathrm{~mm}$. They are covered with cottony wax secretions (Baxendale et al., 1994). The adult female is relatively immobile and is found inside or near the leaf sheath, or behind the leaf axils enclosing the female flower. Clusters of eggs are deposited within a filamentous waxy ovisac. First instars, or crawlers, migrate to new feeding sites and likely play a role in host selection (McKenzie, 1967). Mealybugs are often overlooked in the field because of their small size and hidden location on the plant (Baxendale et al., 1994). Severe mealybug infestations result in a general decline of the buffalograss stand, which can be confused with drought or other stresses. Initially, the turf takes on a reddish-purple discoloration, followed by browning and thinning. A close examination will reveal the mealybug's white cottony secretions.

Possible strategies for managing mealybugs on buffalograss include pesticides, biological control, and use of resistant buffalograsses. Developing mealybug-resistant buffalograsses is of particular importance because this grass is used primarily as a low-input turfgrass species. Fortunately, several resistant buffalograsses have been identified (Johnson-Cicalese et al., 1998). Understanding the mechanism of this resistance would be helpful for formulating optimal strategies for identifying and exploiting new sources of resistance. While considerable progress has been made in identifying germplasm resistant to insect pests, progress toward characterization of the mechanisms conferring the resistance has been limited.

Resistance mechanisms identified in other turfgrass species include: increased tolerance due to greater rhizome numbers, higher stored food reserves, improved turf density and plant vigor; antibiosis factors which reduce survival or oviposition of the insect, for example, endophyte-infection (Acremonium spp.) of the host plant; and antixenosis factors such as leaf size and width, and time of flowering that affect oviposition (Reinert, 1982; Quisenberry, 1990; Johnson-Cicalese et al., 1989). In buffalograss, glabrous leaf surfaces are suspected of playing an important role in mealybug resistance (Johnson-Cicalese et al., 1998). Two glabrous buffalograsses, '609' and 'Prairie', have been shown to be highly resistant to mealybugs, and significant positive correlations were found between leaf pubescence and mealybug infestation levels in several greenhouse screening trials (Johnson-Cicalese et al., 1998).

Pubescence is widely recognized as a factor in plant resistance to insects. Norris and Kogan (1980) provided 55 examples of how pubescence affects the behavioral and physiological response of arthropods to plants. In a third of the cases cited, pubescence increased the susceptibility of the host plant by making it more suitable for oviposition, affecting feeding behavior, or providing protection from predators. Pubescence enhanced oviposition by several lepidopterous insects on a number of plant species (Lambert et al., 1992; Navasero and Ramaswamy, 1991). Pubescent wheats (Triticum spp.) were more heavily infested by airborne wheat curl mites (Eriophyes tulipae Keifer) (Harvey and Martin, 1980). Among several

\footnotetext{
${ }^{1}$ Department of Entomology, University of Nebraska, Lincoln, Nebraska 68583.

${ }^{2}$ Department of Agronomy and Horticulture, University of Nebraska, Lincoln, Nebraska 68583.

${ }^{3}$ Department of Biology, University of San Diego, San Diego, California 92110.
} 
wheatgrass species (Agropyron spp.), pubescence seemed to increase the level of resistance to the black grass bug (Labops hesperius Uhler) (Ling et al., 1985).

A number of researchers have employed scanning electron microscopy (SEM) to characterize the leaf surface and pubescence in plant resistance (Ling et al., 1985; Navasero and Ramaswamy, 1991; Dahlin et al., 1992) and grass morphology studies (Sangster et al., 1983; Chen and Fukuoka, 1991). SEM has also been used to study mealybug anatomy (Cox and Pearce, 1983). The objectives of this study were to use light and scanning electron microscopy (SEM) to disclose morphological differences between mealybugresistant and susceptible buffalograsses, and to enhance our understanding of the underlying resistance mechanisms.

\section{Materials and Methods}

TRICHOME COUNTS AND PUBESCENCE RATINGS. Trichome counts were taken on 16 buffalograsses exhibiting a range of mealybug infestation levels and pubescence ratings (Johnson-Cicalese et al., 1998). These counts were taken to document trichome densities differences among buffalograsses, and to confirm the accuracy of correlations between trichome numbers and pubescence ratings. Pubescence ratings, while subjective, were time-efficient, taking only a few seconds to evaluate each plant. The rating scale was $1-6$, where $1=$ no trichomes and $6=$ very dense trichomes (approximately $30 \%$ of the leaf surface covered) (Johnson-Cicalese et al., 1998).

Plants were maintained under uniform conditions in the greenhouse, under 400-watt HID lamps [photoperiod of 16:8 (L:D) h] and at maximum/minimum temperature settings of $27 / 21^{\circ} \mathrm{C}$. A fully expanded leaf blade was removed from two different pots of each buffalograss and examined. Trichomes seen within an ocular grid at $30 \times$ magnification were counted. Depending on leaf width the area observed was approximately $4 \mathrm{~mm}^{2}$. To determine if trichome density varied from one location on the leaf to another, both the abaxial and adaxial leaf surfaces of an area adjacent to the ligule and $20 \mathrm{~mm}$ from the ligule were examined.

Experimental design was a split-plot; the main unit treatments were 16 buffalograsses in a completely randomized design (two replications), and the subunit treatments were the four locations on the leaf surface. Data were subjected to analysis of variance, and when a significant $F$ ratio occurred $(P<0.05)$, means were compared using the least significant difference test (LSD). Correlations between counts and ratings were also analyzed (SAS Institute, 2002).

SCANNING ELECTRON MICROSCOPY (SEM). SEM was used to examine buffalograss leaf pubescence in greater detail, and to evaluate its possible effect on susceptibility to mealybugs. Two mealybug-susceptible buffalograsses, 85-97 and 378, and two mealybug-resistant buffalograsses, 609 and Prairie plants were examined. Prior to examination, plants were maintained in the greenhouse under the same conditions as previously described. Because mealybugs are typically found on the adaxial surface at the junction of the leaf blade and sheath, this was the primary area examined. The second fully-expanded leaf was examined in all cases. To evaluate mealybug interactions with the plant, nymphs, adults, and mealybug-infested leaves were also examined.

Previous SEM studies involving grasses and mealybugs have utilized several methods of specimen preparation (Cox and Pearce, 1983; Sangster et al., 1983; Chen and Fukuoka, 1991). In this study, two methods were used, fixed and fresh tissues. For fixed tissues, a $10 \mathrm{~mm}$ leaf segment was immersed in $3 \%$ glutaraldehyde in a phosphate buffer for $1 \mathrm{~h}$, dehydrated in an ethanol series $(20 \%, 50 \%, 75 \%, 95 \%$, $100 \%$ ), then critical point dried with $\mathrm{CO}_{2}$ in a Sorvall Critical Point Drying System (Sorvall, Newton, CN 06470). Leaf segments were attached to stubs using double-sided adhesive and immediately coated with 300A Au or Au/Pd in a Denton Desk II cool sputter coater (Denton Vacumm Inc., 1259 North Church St., Moorestown, NJ 08057). Fresh tissues were removed from the plant, mounted directly on stubs and coated similarly to the fixed tissues. Fixed and fresh mealybug specimens were prepared in a similar manner. Specimens were examined under a Cambridge S-90 Stereoscan electron microscope (Leo Electronic Microscopy Inc., One Corporation Way, Peabody, MA 01960).

\section{Results and Discussion}

TRICHOME COUNTS AND PUBESCENCE RATINGS. Significant differences in trichome densities were found among the buffalograsses $(F=15.94$; d.f. $=15,16 ; P<0.0001)$, with number of trichomes ranging from 0 to $11 / \mathrm{mm}^{2}$ (Table 1 ). The buffalograsses $85-97$ and 378 were highly pubescent. The majority of buffalograsses, however, were intermediate in trichome density, and a few buffalograsses, including 609, 'Buffalawn', 84-412, and Prairie, had almost no trichomes. There were significantly more 
Table 1. Trichome numbers and pubescence ratings of 16 buffalograsses.

\begin{tabular}{lccc}
\hline & \multicolumn{2}{c}{ Mean Trichomes $^{*}$} & Pubescence \\
\cline { 2 - 3 } Selection & Abaxial \pm SEM $^{\dagger}$ & Adaxial $\pm \mathrm{SEM}$ & Ratings $^{\ddagger}$ \\
\hline Buffalawn & $0.0 \pm 0$ & $0.1 \pm 0.1$ & 1.0 \\
'609' & $0.0 \pm 0$ & $0.0 \pm 0$ & 1.1 \\
$84-412$ & $0.0 \pm 0$ & $0.2 \pm 0.2$ & 1.0 \\
Prairie & $0.1 \pm 0.1$ & $0.2 \pm 0.1$ & 1.7 \\
$84-714$ & $0.2 \pm 0.1$ & $4.1 \pm 1.8$ & 2.8 \\
$85-204$ & $3.3 \pm 0.2$ & $3.6 \pm 0.5$ & 4.0 \\
$85-25-2$ & $4.8 \pm 1.5$ & $2.9 \pm 0.7$ & 4.0 \\
'315' & $7.7 \pm 1.0$ & $5.4 \pm 0.6$ & 3.4 \\
$84-931$ & $6.6 \pm 1.1$ & $4.4 \pm 1.0$ & 4.8 \\
$85-217$ & $6.4 \pm 0.6$ & $5.1 \pm 0.9$ & 5.0 \\
$84-22-2$ & $6.0 \pm 0.3$ & $5.5 \pm 0.8$ & 4.8 \\
$84-924$ & $8.6 \pm 1.5$ & $5.9 \pm 1.0$ & 3.8 \\
$84-W S$ & $8.8 \pm 1.7$ & $4.9 \pm 1.1$ & 4.5 \\
$85-33$ & $7.4 \pm 0.5$ & $6.2 \pm 0.5$ & 4.8 \\
'378'* & $10.9 \pm 1.4$ & $5.2 \pm 0.9$ & 4.5 \\
$85-97$ & $8.7 \pm 1.1$ & $7.7 \pm 1.1$ & 5.6 \\
LSD(.05) & 2.2 & 1.7 & 0.6 \\
Mean & 5.0 & 3.8 & 3.6 \\
\hline
\end{tabular}

* Mean number (adjacent to and $20 \mathrm{~mm}$ from ligule) of trichomes per $\mathrm{mm}^{2}$ of leaf blade.

$\uparrow$ Standard error of the mean.

* Pubescence ratings of whole plants (1-6 scale, where $1=$ none).

$\S$ Mealybug-resistant standard.

** Mealybug-susceptible standard.

trichomes on abaxial surfaces of leaf blades than on adaxial surfaces $(F=16.12$; d.f. $=1,80 ; P<0.0001)$, although the differences were relatively small $\left(\right.$ abaxial $=5.0 / \mathrm{mm}^{2}$, adaxial $=3.8 / \mathrm{mm}^{2}$ ). On the adaxial side, significantly more trichomes were found adjacent to the ligule $\left(4.4 / \mathrm{mm}^{2}\right)$ as opposed to $20 \mathrm{~mm}$ from the ligule $\left(3.3 / \mathrm{mm}^{2}\right)(F=15.48$; d.f. $=1,17 ; P<0.0011)$; whereas on the abaxial side, the difference was not significant (adjacent: 5.1/ $\left.\mathrm{mm}^{2}, 20 \mathrm{~mm}: 4.8 / \mathrm{mm}^{2}\right)(F=0.99$; d.f. $=1,16 ; P<0.34)$. These relatively small differences among the four locations suggest that trichomes are uniformly distributed over the leaf surface (data not shown for the four locations). A primary reason for taking trichome counts was to compare trichome densities with pubescence ratings. Highly significant positive correlations were found between pubescence ratings and trichome numbers in all four positions on the leaf (abaxial/adjacent: $r^{2}=$ $0.79, P=0.0002$; abaxial $/ 20 \mathrm{~mm}: r^{2}=0.85, P=0.0001$; adaxial/adjacent: $r^{2}=0.90, P=0.0001$; and adaxial $\left./ 20 \mathrm{~mm}: r^{2}=0.89, P=0.0001\right)$. These results indicate that a visual assessment of the whole plant, using a 1-6 rating scale, is an accurate and efficient method for assessing plant pubescence.

Leaf width measurements were also taken for the 16 buffalograsses (data not shown), and no significant differences were found $(F=1.19$; d.f. $=14,30 ; P<0.33)$. The mean leaf width was $1.7 \mathrm{~mm}$ and the range was 1.2-2.1 mm. Since leaf blade width has been shown to affect resistance to insects in other grass species (Ahmad and Funk, 1982), it was useful to eliminate this variable as a possible resistance factor in buffalograss.

Of particular interest in these pubescence evaluations was our observation that most of the buffalograsses with glabrous leaves had a lower ploidy level, and exhibited poor winter hardiness in Nebraska field trials. Geographic distribution of buffalograss is believed to be related to its ploidy level, with diploid buffalograsses occurring only in Central Mexico and Texas, tetraploids occurring in Mexico, Texas and a narrow band along the eastern slope of the Rocky Mountains, and hexaploids primarily throughout the central and northern Great Plains (Huff et al., 1993). The diploid cultivar, Buffalawn (Table 1) was glabrous. This diploid suffers severe winter injury in Nebraska (Riordan et al., 1995). Both Prairie and 609 have a tetraploid chromosome number, are free of pubescence (Table 1) and lack winter hardiness. The ploidy level of the glabrous buffalograss, 84-412 (Table 1), is unknown but was originally collected in Dallas, TX. All of the other selections evaluated are pubescent and believed to be hexaploids. They are all relatively winter hardy. 

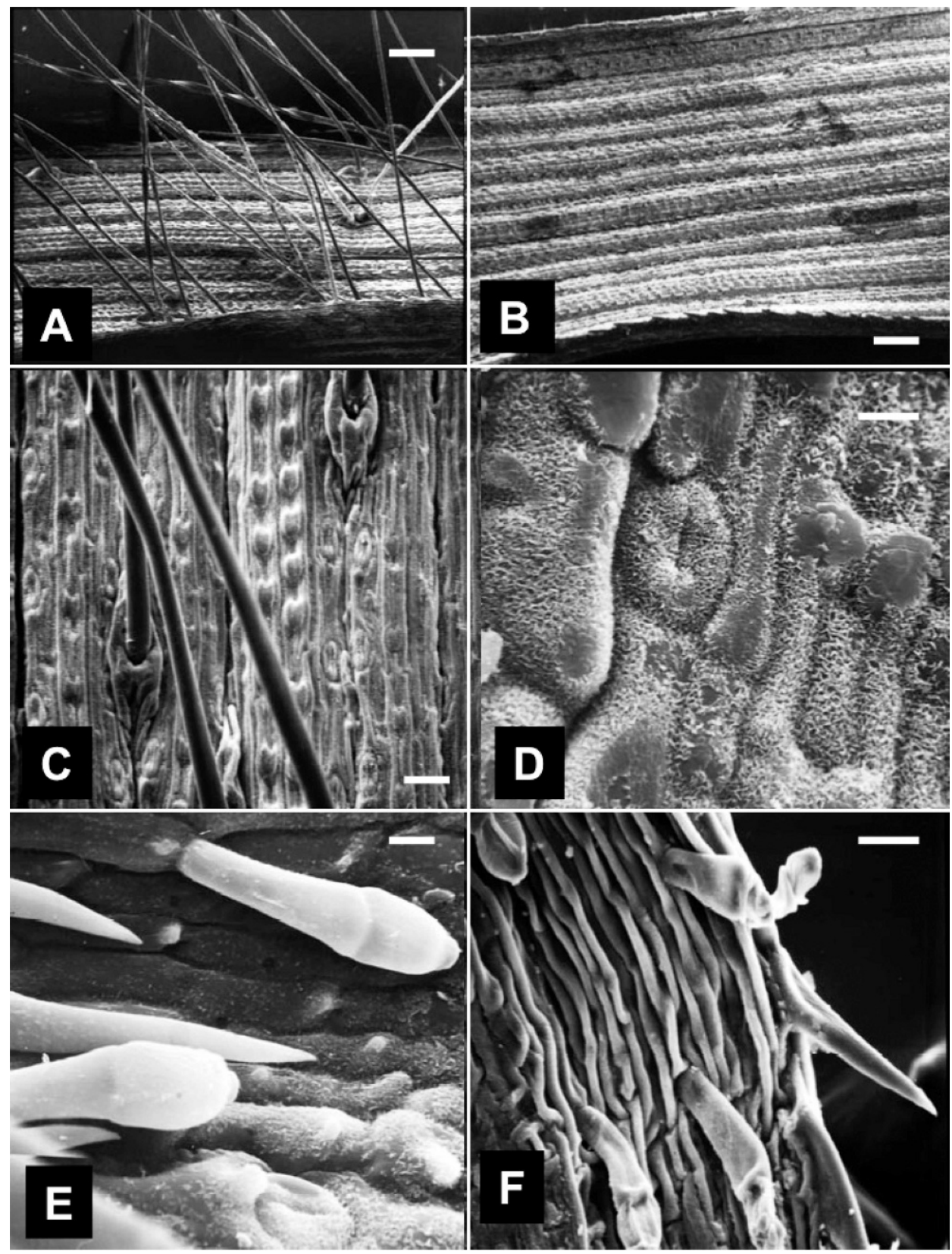

Fig. 1. Buffalograss leaf surface. (A) Dense pubescence on adaxial leaf surface of mealybug-susceptible selection 85-97 (fresh tissue; scale bar $=0.1 \mathrm{~mm}$ ). (B) Glabrous, adaxial leaf surface of resistant cultivar 609 (fresh tissues; scale bar $=0.1 \mathrm{~mm}$ ). (C) Closeup of trichomes on abaxial leaf surface of 378 (fixed tissue; scale bar $=0.03 \mathrm{~mm}$ ). (D) Waxy platelets and stomate on adaxial leaf surface of 609 (fixed tissue; scale bar $=0.005 \mathrm{~mm}$ ). (E) Glandular trichomes in ligule area of 609 leaf (fixed tissue; scale bar $=0.005$ $\mathrm{mm}$ ). (F) Shrunken glandular trichomes and leaf tissue of 609 (fresh tissue; scale bar $=0.02 \mathrm{~mm}$ ). 

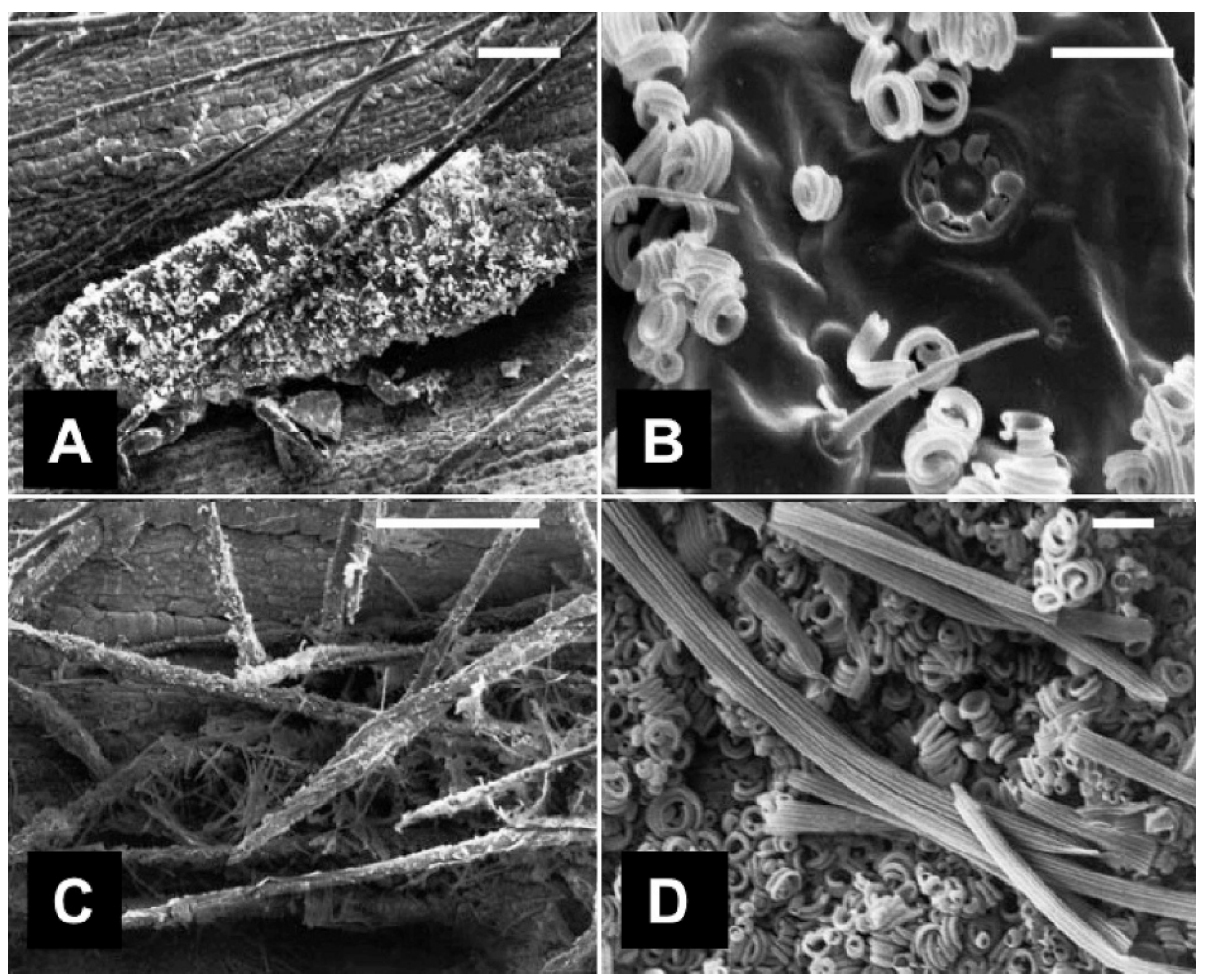

Fig. 2. Mealybug/buffalograss interaction. (A) Mealybug nymph on 85-97 leaf (fixed tissue; scale bar $=$ $0.1 \mathrm{~mm}$ ). (B) Surface of mealybug illustrating waxy secretions, simple setae, and wax-producing pore (fixed tissue; scale bar $=0.004 \mathrm{~mm}$ ). (C) 85-97 leaf surface with large quantities of mealybug wax adhering to the trichomes (fixed tissue; scale bar $=0.1 \mathrm{~mm}$ ). (D) Close-up of mealybug wax on leaf surface, note long hollow tubes and curled filaments (fresh tissue; scale bar $=0.004 \mathrm{~mm}$ ).

Trichome density and resistance to mealybugs may be related to ploidy level or adaptation. Both tetraploid selections (609 and Prairie) were highly resistant to mealybugs and 84-412 was moderately resistant (Johnson-Cicalese et al., 1998). The association between mealybug resistance and ploidy level is generally consistent with the understanding that higher ploidy levels offer an advantage for improved adaptation due to the dosage effects of multiple alleles (Paterson, 2005).

SCANNING ELECTRON MICROSCOPY. SEM examination revealed numerous simple trichomes on the adaxial surface of the mealybug susceptible buffalograsses, 85-97 (Fig. 1A) and 378, and almost no trichomes on the mealybug resistant buffalograsses, 609 (Fig. 1B) and Prairie (SEM images not shown for 378 and Prairie). Raised cells surrounded the base of each trichome and the trichome surface was smooth (Fig. 1C). At higher magnification, a dense covering of waxy platelets was observed covering the leaf surface (Fig. 1D). This wax may be a factor in the drought resistance exhibited by buffalograss. Glandular trichomes were found in the ligule area of both the resistant and susceptible buffalograsses (Fig. 1E and $1 F)$. The significance of these trichomes on buffalograss is unknown. In other plant species, glandular trichomes exude sticky or toxic substances and can be important in plant resistance to insects (Norris and Kogan, 1980).

A comparison of tissue preparation methods can be observed in Fig. 1E and 1F. The glandular trichomes on the fresh tissue sample (Fig. 1F) are shrunken and shriveled compared to the trichomes on the critical point dried sample (Fig. 1E). This shrunken appearance was observed in several fresh tissue samples. Fresh tissue is simpler to prepare, but this approach can result in distortion of samples and possible misinterpretation of results.

Examination of in situ mealybugs with light and scanning electron microscopy (Fig. 2) provided valuable clues to how this insect interacts with trichomes and the leaf surface. Young nymphs (crawlers) fit 
between the trichomes, so pubescence probably does not hinder movement or feeding (Fig. 2A). In fact, the trichomes may actually provide a foothold. The abundant waxy secretions produced by mealybugs may interact with leaf trichomes and thus provide a more suitable environment for feeding and oviposition (Fig. 2B-D). Close-ups of the mealybug's cuticle reveal curved filaments of secreted wax and a waxproducing pore (Fig. 2B). Cox and Pearce (1983) discussed the function of the various forms of mealybug wax (see Fig. 2D). They suggested the curled filaments serve to protect the mealybug from their own honeydew by coating the droplets with wax. The long hollow tubes and shorter curled filaments are constituents of the ovisac and male cocoon. In buffalograss, leaf trichomes may provide a framework which supports the waxy filamentous ovisac and provides protection for eggs and newly emerged nymphs. Fig. 2C shows how mealybug wax has glued the trichomes together.

These SEM evaluations and a review of the literature (Norris and Kogan, 1980) suggest that pubescence may facilitate oviposition and provide a foothold for early-instar mealybugs. It is also possible that airborne mealybug crawlers are captured by the leaf trichomes, as occurs with the wheat curl mite (Harvey and Martin, 1980). Mealybug nymphs are known to climb to the upper leaves and tips of plants where they become airborne and are carried to new hosts (Nwanze, 1978). Leaf pubescence may also help prevent the parasitoid wasps that are known to be associated with these mealybugs (Heng-Moss et al., 1998, 1999) from successfully parasitizing mealybug nymphs. Finally, highly pubescent leaves may alter the microenvironment of the leaf and provide a more favorable environment for mealybug development.

This research provides the first evidence that pubescent leaves increase buffalograss susceptibility to mealybugs, and suggests new avenues for further investigation. Specifically, future studies should focus on improving our understanding of the interactions among trichome density, ploidy level, adaptation, and resistance to mealybugs.

\section{Acknowledgments}

We gratefully acknowledge Z B Mayo, G. Horst and L. Young for their advice, K. Lee and J. Rosowski for assistance with SEM studies, S. Frana for assistance with trichome counts, and T. Weinhold and A. Kramer (University of Nebraska-Lincoln) for additional technical assistance. This work was supported in part by the United States Golf Association, the Nebraska Turfgrass Foundation, and the Agricultural Research Division, University of Nebraska-Lincoln.

\section{Literature Cited}

Ahmad, S., and C. R. Funk. 1982. Susceptibility of Kentucky bluegrass cultivars and selections to infestations of and injury by the bluegrass billbug (Coleoptera:Curculionidae). New York Entomological Society 29:31-34.

Baxendale, F. P., J. M. Johnson-Cicalese, and T. P. Riordan. 1994. Tridiscus sporoboli and Trionymus sp. (Homoptera: Pseudococcidae): Potential New Mealybug Pest of Buffalograss Turf. Journal of Kansas Entomological Society 67:169-172.

Chen, C., and H. Fukuoka. 1991. Comparison of inflorescence morphology and leaf anatomy between ryegrass, tall fescue and their hybrids. Proceedings of Faculty of Agriculture Kyusha Tokai University 10:57-65.

Cox, J. M., and M. J. Pearce. 1983. Wax produced by dermal pores in three species of mealybug (Homoptera:Pseudococcidae). International Journal of Insect Morphology and Embryology 12:235-248.

Dahlin, R. M., M. A. Brick, and J. B. Ogg. 1992. Characterization and density of trichomes on three common bean cultivars. Economic Botany 46:299-304.

Ferris, G. F. 1950. Atlas of the scale insects of North America (Series V). Stanford University Press, Stanford, California. pp. 1-278.

Ferris, G. F. 1953. Atlas of the scale insects of North America (Series VI). Stanford University Press, Stanford, California. pp. 279-506.

Harvey, T. L., and T. J. Martin. 1980. Effects of wheat pubescence on infestations of wheat curl mite and incidence of wheat streak mosaic. Journal of Economic Entomology 73:225-227.

Heng-Moss, T. M., F. P. Baxendale, and T. P. Riordan. 1998. Rhopus nigroclavatus (Ashmead) and Pseudaphycus sp. (Hymenoptera: Encyrtidae): two parasitoids of the buffalograss mealybugs Tridiscus sporoboli and Trionymus sp. Journal of Kansas Entomological Society 71:8586. 
Heng-Moss, T. M., F. P. Baxendale, T. P. Riordan, and L. J. Young. 1999. The influence of Rhopus nigroclavatus (Ashmead) (Hymenoptera: Encyrtidae) on the buffalograss Mealybugs Tridiscus sporoboli (Cockerell) and Trionymus sp. Environmental Entomology 28:123-127.

Huff, D. R., R. Peakall, and P. E. Smouse. 1993. RAPD variation within and among natural populations of outcrossing buffalograss [Buchloe dactyloides (Nutt.) Engelm.]. Theoretical and Applied Genetics. 86:927-934.

Johnson-Cicalese, J. M., R. H. Hurley, G. W. Wolfe, and C. R. Funk. 1989. Developing turfgrasses with improved resistance to billbugs. 6th International Turfgrass Research Conference, Tokyo 1996:107-111.

Johnson-Cicalese, J. M. 1995. Buffalograss Resistance to Mealybugs: Germplasm Evaluation, Mechanisms and Inheritance. Ph.D. Dissertation, University of Nebraska; Lincoln, Nebaska.

Johnson-Cicalese, J. M., F. P. Baxendale, T. P. Riordan, and T. M. Heng-Moss. 1998. Screening Turf-type Buffalograss Germplasm for Resistance to Mealybugs (Homoptera: Pseudococcidae). Journal of Economic Entomology 91:340-346.

Lambert, L., R. M. Beach, T. C. Kilen, and J. W. Todd. 1992. Soybean pubescence and its influence on larval development and oviposition preference of Lepidopterous insects. Crop Science 32:463-466.

Ling, Y. H., W. F. Campbell, B. A. Haws, and K. H. Asay. 1985. Scanning electron microscope studies of morphology of range grasses in relation to feeding by Labops hesperius. Crop Science 25:327-332.

McKenzie, H. L. 1967. Mealybugs of California. University of California Press, Berkeley, California.

Navasero, R. C., and S. B. Ramaswamy. 1991. Morphology of leaf surface trichomes and its influence on egglaying by Heliothis virescens. Crop Science 31:342-353.

Norris, D. M., and M. Kogan. 1980. Biochemical and morphological bases of resistance. pp. 23-62. In F. G. Maxwell and P. R. Jennings (eds.). Breeding Plants Resistant to Insects. Wiley, New York, New York.

Nwanze, K. F. 1978. Biology of the cassava mealybug, Phenacoccus manihoti Mat.-Ferr in the Republic of Zaire. pp. 20-28. In K. F. Nwanze and K. Leuschner (eds.). Proceeding of the Internation Workshop on the Cassava Mealybug, Phenacoccus manihoti Mat.-Ferr (Pseudococcidae). International Institute of Tropical Agriculture, Ibadan, Nigeria.

Paterson, A. 2005. Polyploidy, evolutionary opportunity, and crop adaptation. pp. 191-196. In R. Mauricio (ed.). Genetics of Adaptation. Springer-Verlag, New York, New York.

Quisenberry, S. S. 1990. Plant resistance to insects and mites in forage and turf grasses. Florida Entomologist 73:411-421.

Reinert, J. A. 1982. A review of host resistance in turfgrasses to insects and acarines with emphasis on the southern chinch bug. pp. 3-12. In H. D. Niemczyk and B. G. Joyner (eds.). Advances in Turfgrass Entomology. Hammer Graphics, Inc., Piqua, Ohio. 150 pp.

Riordan, T. P., S. A. de Shazer, J. M. Johnson-Cicalese, and R. C. Shearman. 1993. An overview of breeding and development of buffalograss. International Turfgrass Society Research Journal 7:816-822.

Riordan, T. P., J. M. Johnson-Cicalese, C. A. Rodgers, T. Heng, A. Kramer, and L. Wit. 1995. Performance of buffalograss cultivars and selections in several breeding and evaluation trials. Turfgrass Research Report for 1994. University of Nebraska, CGS 95-2.

Sangster, A. G., M. J. Hodson, D. W. Parry, and J. A. Rees. 1983. A developmental study of silification in the trichomes and associated epidermal structures of the inflorescence bracts of the grass, Phalaris canariensis L. Annals of Botany 52:171-187.

SAS Institute. 2002. PROC user's manual, version 9.1. SAS Institute, Cary, North Carolina. 